\title{
Art Music by Caribbean Composers: Jamaica
}

\section{Christine Gangelhoff Cathleen LeGrand \\ The College of The Bahamas ${ }^{1}$}

\section{INTRODUCTION}

Jamaica is among the Caribbean islands that Columbus claimed for Spain. The island was captured by the British in 1655 and remained a British colony until its independence in 1962 (Jamaica, 2005). Jamaica was settled by Europeans who brought in a large number of African slaves to perform agricultural work, mainly on sugar plantations. Workers from Asia, predominantly from India and China, who arrived after Emancipation also contribute to the nation's diversity. In response to its rich diversity, the motto of Jamaica is: Out of Many, One People.

"Jamaican music is as varied as the people who inhabit the island... [M] uch folk music retains features and functions of black African music, blended with elements of European (primarily British) music" (Lewin \& Gordon, 2007-2011). Jamaican musical genres, such as ska, rocksteady, reggae, and dancehall, are popular and influential internationally.
The classical music tradition in Jamaica dates back to the 18th century. The "first oratorio written in the Americas," Jonah, was composed by Samuel Felsted sometime around 1773 (Lumsden, 2004). Sir Frederic $\mathrm{H}$. Cowen, the most prolific Jamaican classical composer, created a long list of works including several operas. Cowen moved to England during his youth and, in addition to composing, had a notable career as a performer and conductor (Lumsden, 2003). Peter Ashbourne is the most versatile of the younger generation of composers born and living in Jamaica. One of his recent works, Mikey, a reggae opera, displays his innovative approach to composition. Ashbourne points out that "when you consider that, in terms of popular culture, Jamaica has an unusually high profile, [and] art music is easily overshadowed by the more conspicuous and populist genres. There is very little in the way of financial support [or] sponsored training [for art music]" (P. Ashbourne, personal communication, May 6, 2011).

\footnotetext{
${ }^{1}$ Christine Gangelhoff, Assistant.Professor, School of Communication and Creative Arts: Cathleen LeGrand, Public Services Librarian, Libraries and Instructional Media Services, The College of The Bahamas, P.O. Box N-4912, Nassau, Bahamas.

Cathleen LeGrand is now Librarian, at Royal Thimphu College, Ngabiphu, Thimphu, Bhutan.

Acknowledgments: The authors would like to thank Peter Ashbourne, Rosina Moder, Paul Shaw, and Roger Williams for their help in compiling this chapter.

The authors are grateful to The College of The Bahamas for the grant that made this research possible. E-mail: cgangelhoff@cob.edu.bs

How to cite this article in APA $6^{\text {th }}$ ed. style: C. Gangelhoff, \& LeGrand, C. (2011). Art music by Caribbean composers: Jamaica. The International Journal of Bahamian Studies, 17(1), 43-52. https:// doi.org/10.15362/ijbs.v17i1.153
}

(c) C. Gangelhoff \& C. LeGrand, 2011. Journal compilation (c)The International Journal of Bahamian Studies, 2011. 
Describing his compositional approach, Ashbourne states:

Jamaica is a small island in the Caribbean basin that is remarkably rich in folk material. The quality and quantity are both impressive. [This richness helps to explain] why I want to examine this folk tradition [as a] resource. Some very interesting music can result when these tuneful, mostly diatonic melodies are subjected to various compositional techniques. The tonal basis of this traditional music can be conveniently integrated with my current approach to the musical poles of tonality and atonality. (Personal communication, May 6, 2011)

Oswald Russell's THREE JAMAICAN DANCES is an example of a classical work that incorporates folk music; the piece is based on Jamaican folk songs. JAMAICAN PIANIST PAUL SHAW discusses the second movement, which is based on the folk song, Sammy Dead:
As simple as that folk song is, Oswald Russell takes the melody ... he layers over it a rhythm (like this, an ostinato), and as it turned out from some of the research that I've done ... that rhythm - you hear it in a lot of Caribbean music - comes all the way from West Africa (Shaw, 2010).

The Edna Manley College offers several music-related degrees: an Associate of Arts in Music, a Bachelor of Music in Classical Performance, Jazz and Popular Music Studies, and a Bachelor of Music Education. Two other institutions, Northern Caribbean University and Mico University College, also offer a Bachelor of Music Education. The National Youth Orchestra of Jamaica (NYOJ) trains young people to play orchestral instruments. The NYOJ is a private nonprofit orchestra, offering no-cost music lessons, and uses the El Sistema program of orchestral instrument education pioneered in Venezuela.

\section{REFERENCES}

Jamaica. (2005). In Continuum: Encyclopedia of popular music of the world. http://www.credoreference.com/entry/contp $\mathrm{mwl} /$ jamaica

Lewin, O., \& Gordon, M. G. (2007-2011). Jamaica. Grove Music Online / Oxford Music Online. http://www.oxfordmusiconline.com
Lumsden, J. (2003). Frederic H. Cowen: A famous Jamaican composer. Jamaica's classical musicians. http://www.joyousjam.com/jamaicasclassica lmusicians/id7.html

Lumsden, J. (2004). Samuel Felsted, organist and composer. Jamaica's classical musicians. www.joyousjam.com/ jamaicasclassicalmusi cians/id8.html 


\section{COMPOSERS}

Eleanor Alberga (1949-)

Peter Ashbourne (1950-)

Paulette Bellamy

Frederic Hyman Cowen (1852-1935)

Noel Dexter

Samuel Felsted (1743-1802)

Orville Hammond

Andrew Marshall

Oswald Russell (1933-)

Don Shirley (1927-)

Stephen Earl Tucker

Marjorie Whylie

COMPOSITIONS

\section{Alberga}

Animal banter

Chasm (for piano)

Clouds

Dancing with the shadow (1990; ballet score)

De profundis (for voice)

Fizz (for piano)

Glinting glancing shards

Her lament: one Cezanne apple (for voice)

Hill \& gully ride (for piano)

Ice flow (for piano)

If the silver bird could speak (for piano)

Jamaican medley (for piano)

Letters of a love betrayed (Chamber opera; Based on a story from Isabel Allende's Eva Luna)

My heart danceth (for voice)

Mythologies (for orchestra)

Nightscape (the Horniman serenade)

No-man's land lullaby
On a bat's back I do fly

Only a wish away (for piano)

Piano quintet

Remember

Resolution

Roald Dahl's "Snow White \& the Seven Dwarfs" (for orchestra)

String quartet, no. 1

String quartet, no. 2

String quartet, no. 3

Sun warrior (for chamber orchestra)

3-day mix (for piano)

Two-piano suite

Violin concerto

The wild blue yonder

\section{Ashbourne}

Alleluia (1995; choral concert, with drums)

Avia (1986; for wind ensemble)

Carib colours (2002; for orchestra)

Elena and her variations (1985; with soprano recorder solo)

Five songs (2005; for high voice \& piano)

The fly, the bell and the bicycle (1984; for chamber orchestra)

Folk suite (1996; for string quartet)

The hidden garden (2010; for oboe \& strings)

Jamaica folk (1985; for string quartet)

Jamaican suite (1981; for symphonic wind ensemble)

Little prelude (1984; for flute \& string quartet)

Mapadua (2010; for chamber orchestra)

Medley of Jamaican folk tunes (1963; for violin \& piano)

Mikey (2011; reggae opera) 
O'er our Blue Mountain (2009; for string quartet)

Parakeet in de garden (2003; for soprano, clarinet \& piano; or tenor, flute \& piano)

Ring games and jubilee (2003; for chamber orchestra)

\section{Bellamy}

Improvisations of jackass a jump and bray

\section{Cowen}

All hail the glorious reign (1897)

Barbaric march (1883)

The butterfly's ball (1901)

Christmas scenes (1894)

Concertstück (1900; for piano \& orchestra)

La coquette (1873; for piano)

Coronation march (1902)

The corsair (1876)

Cupid's conspiracy (1918; comedy ballet)

A daughter of the sea (1896)

The deluge (1878; oratorio)

Deux morceaux (1901)

Melodie

Ál'espagne

The dream of Endymion (1897; for tenor \& orchestra)

The fairies' spring (1891)

Festival overture (1872)

Flower fairies (for piano)

Four old English dances

Set 1 (1896)

Set 2 (1905)

Garibaldi, or the rival patriots (1860; operetta)

He giveth His beloved sheep (1907; oratorio)

Harold, or the Norman conquest (1895; opera)

In fairyland: Suite de ballet (1896)
In the olden time, Suite, in D major (1883; for strings)

Indian rhapsody (1903)

Jephthah (1900; oratorio, unfinished)

John Gilpin (1904; for chorus \& orchestra)

The language of flowers: Suite de ballet, Set 1 (1880)

The language of flowers: Suite de ballet, Set 2 (1914)

The magic goblet: The luck of Edenhall (1934; for orchestra)

March (1886)

Miniature variations (1934)

Minna-waltz (1858; for piano)

Monica's blue boy (1917; pantomime)

The months (1912)

Niagara, characteristic overture, in C major (1881)

Nights of music (1900; for violins)

Ode to the passions (1898; for chorus \& orchestra)

One too many (1874; operetta)

Overture, in D minor (1866)

Pauline (1876; opera)

Piano concerto, in A minor (1869)

Piano trio, no. 1, in A major (1865)

Piano trio, no. 2, in A minor (1868)

A phantasy of life and love (1901)

Reverie (1903; for violin \&orchestra)

The rose maiden (1870)

The rose of life (1895)

Ruth (1887; oratorio)

Signa (1893; opera)

Sinfonietta, in A major (1881)

Sleeping beauty (1885; cantata)

Snowflakes (for voice \& piano) 
The spirit of carnival (operetta, unfinished)

St. John's eve (1889)

St. Ursula (1881)

String quartet, in C minor (1866)

Summer on the river (1893)

Symphony, no. 1, in C minor (1869)

Symphony, no 2, in F major (1872)

Symphony, no.3, in C minor (The

Scandinavian) (1880)

Symphony, no. 4, in B flat minor (The Welsh) (1884)

Symphony, no. 5, in F major (1887)

Symphony, no. 6, in E major (Idyllic) (1897)

Thorgrim (1890; opera)

The transfiguration (1895; oratorio)

Three valses caprices (for piano)

Two pieces (1903; for orchestra)

The veil (1910; cantata)

Village scenes (1893)

The water lily (1893)

\section{Dexter}

I come to the cross (for choir, piano \& percussion)

The Lord is my shepherd (for choir, piano \& percussion)

Lord, make us one (for choir, piano \& percussion)

O praise ye the Lord (for choir, piano \& percussion)

The official university song (University of the West Indies)

The right hand of God

\section{Felsted}

Jonah: An oratorio (c.1775; for chorus \& piano)

Six voluntaries to the organ or harpsichord (c. 1793)

\section{Russell}

The beachcomber (for flute)

Berceuse (1993; for piano)

Caraïbes (for wind ensemble)

D’alpha en alpha

Élégie (The lone tree by the sea) (for cello)

Games of arms (1963; ballet)

Humoresque, no.1 (for piano)

Legends of lover's leap (1962; ballet)

Papillons (for piano)

Rhapsody (1988)

Three dance movements (for percussion)

Three Jamaican dances (for piano)

1. Allegro moderato

2. Andante moderato

3. Allegro

Les vielles lunes (1969; film score)

\section{Tucker}

After the late, late show: Fanfare for wind quintet

Locked in

Prelude for Flute and Piano

Transformations

\section{SCORES}

\section{Alberga}

Myers, T. (Ed.). (2006). Spectrum: 20 contemporary works for solo piano. London, England: ABRSM Publishing. (OCLC\# 265722383)

[Includes music for If the silver bird could speak] 
Nyaho, W. H. C. (Ed.). (2009). Piano music of Africa and the African diaspora, Vol. 2. New York, NY: Oxford University Press.

[Includes music for If the silver bird could speak]

\section{Cowen}

Bingham, C., \& Cowen, F. H. (2010). A daughter of the sea: Cantata for female voices, with pianoforte accompaniment. Whitefish, MT: Kessinger Pub. (ISBN: 1161755861)

Bingham, C., \& Cowen, F. H. (2010). Village scenes: Cantata for female voices, with pianoforte accompaniment. Whitefish, MT: Kessinger Pub. (ISBN: 1161954929)

The butterfly's ball. (1901). London, England: Novello. Retrieved from International Music Score Library Project website: http://imslp.org/wiki/The_Butterfly\%27s_B all_\%28Cowen,_Frederic_Hymen\%29

Collins, W., \& Cowen, F. H. (2010). Ode to the passions: Set to music for chorus and orchestra. Charleston, SC: Nabu Press. (ISBN: 1148968547)

Four English dances in the olden style. (n.d.) John Ebenezer West, arranger. London, England: Merton Music. Retrieved from International Music Score Library Project website: http://imslp.org/wiki/4_English_Dances_in_ the_Olden_Style_\%28Cowen,_Frederic_Hy men\%29

Francillon, R. E., \& Cowen, F. H. (2010). Saint Ursula: Sacred cantata. Whitefish, MT: Kessinger Pub. (ISBN: 1162210818)

Home, F. W., \& Cowen, F. H. (1893). A lover's counsel: A four-part song. The Musical Times and Singing Class Circular, 34(608), 605-6. doi:10.2307/3362225
Hueffer, F., \& Cowen, F. H. (2010). Sleeping beauty: A cantata in a prologue and four scenes. Whitefish, MT: Kessinger Pub. (ISBN: 1162211512)

Moore, T., \& Cowen, F. H. (1906, May 1.). Come, May, with all thy flower: A four-part song. The Musical Times, 47(759), 327-31. doi:10.2307/904502

Snowflakes. (n.d.). London, England: Williams. Retrieved from University of Rochester website: http://hdl.handle.net/1802/8964

Symphony, no. 3 (The Scandinavian). (1884). Vienna, Austria: Gutman. Retrieved from University of Rochester website: http://hdl.handle.net/1802/10041

Symphony, no. 4 (The Welsh). (n.d.). London, England: Novello, Ewer \& Co. Retrieved from International Music Score Library Project website: http://imslp.org/wiki/Symphony_No.4_\%27 The_Welsh\%27_\%28Cowen,_Frederic_Hy men\%29

Symphony, no. 5. (n.d.) London, England: Novello. Retrieved from International Music Score Library Project website: http://imslp.org/wiki/Symphony_No.5_\%28 Cowen,_Frederic_Hymen\%29

Wensley, S., \& Cowen, F. H. (2010). Summer on the river: Cantata for female voices. Whitefish, MT: Kessinger Pub. (ISBN: 1162242701)

\section{Dexter}

Dolan, M. (Ed.). (2002). Let the peoples sing: Sacred choral music of the Caribbean. Minneapolis, MN: Augsburg Fortress. [Includes I come to the cross; The Lord is my shepherd; Lord, make us one; O praise ye the Lord] 
The right hand of God. (1981). Bridgetown, Barbados: Caribbean Conference of Churches. Retrieved from

http://www.oikoumene.org/fileadmin/files/w cc-

main/2007pdfs/WoPCUsongs/The_right_ha nd_of_God_Eng.pdf

\section{Felsted}

Dox, T. J. (Ed.). (1994). Jonah: An oratorio, 1775. Chapel Hill, NC: Hinshaw Music. (HMB-193)

\section{Russell}

The beachcomber. (n.d.). Essex, England: United Music Publishers.

Caraïbes. (n.d.). [Photocopy of manuscript]. (Available at New York Public Library, Performing Arts Research collections: Call \# JMH 93-122)

Elegie (The lone tree by the sea). (n.d.). Essex, England: United Music Publishers.

Humoresque, no. 1. (n.d.). Essex, England: United Music Publishers.

Jamaican dances. (n.d.). Essex, England: United Music Publishers.

Nyaho, W. H. C. (Ed.). (2009). Piano music of Africa and the African diaspora, Vol. 3. New York, NY: Oxford University Press.

[Vol.3 includes music for Jamaican dance, no. 2 and Papillons]

Nyaho, W. H. C. (Ed.). (2009). Piano music of Africa and the African diaspora, Vol. 5. New York, NY: Oxford University Press.

[Vol. 5 includes music for Humoresque, no. 1]

Three dance movements. (n.d.). Essex, England: United Music Publishers.

\section{RECORDINGS}

\section{Alberga}

British women composers, vol. 2 [CD]. (1992). London, England: Lorelt. (LNT 103: one disc)

Track 11. Suite from "Dancing with the Shadow": Duo (4:53)

Track 12. Suite from "Dancing with the Shadow": Quintet (6:43)

Track 13. Suite from "Dancing with the Shadow": Sextet (3:23)

\section{Bellamy}

Shaw, P. (2001). Le grand tour: Paul Shaw plays Caribbean art music [CD].

[Includes Improvisations on jackass a jump and bray]

\section{Cowen}

Symphony, no.3; Indian rhapsody[CD]. (2009). [Recorded by Czechoslovak State Philharmonic Orchestra; Adrian Leaper, conductor]. Hong Kong: Marco Polo-Naxos. (Marco Polo: 8.223273; one disc, 67:14)

Track 1. The butterfly's ball (11:56)

Track 2. Indian rhapsody (15:58)

Track 3. Symphony, no. 3: Allegro moderato ma con moto (11:47)

Track 4. Symphony, no. 3: A summer evening on the fjord: Adagio con moto allegretto (10:17)

Track 5. Symphony, no. 3: Scherzo: Molto vivace quasi presto (6:30)

Track 6. Symphony, no. 3: Finale: Allegro ma non troppo (10:45) 
Symphony, no. 6, in E major (The idyllic) [CD]. (2006). [Recorded by Aarhus Symphony Orchestra; Bostock, Douglas, conductor]. Frederiksberg, Denmark: Classico. (CLASSCD684; one disc).

Track 1. Allegro vivace - più mosso - poco più risoluto - poco più animato

Track 2. Allegro scherzando - poco tranquillo

Track 3. Adagio, molto tranquillo

Track 4. Finale. Molto vivace

\section{Felsted}

Lift every voice and sing [CD]. (2002). [Recorded by University of the West Indies Singers]. Kingston, Jamaica: University of the West Indies. (OCLC\# 646071519)

Track 2. "Tune your harps" from Jonah

Music for the colonial band [CD]. (1976).

[Recorded by Colonial Band of Boston; David P. McKay, conductor]. Washington, DC: Folkways Recordings. (FW32378; one disc)

Track 108. "Save Me O Lord” from Jonah

Music for the colonial orchestra: 18th century American orchestra music. (2003).

[Recorded by Wayland Consort Orchestra; David P. McKay, conductor]. Washington, DC: Folkways Recordings. (FW32380; one disc)

Track 203. "Save me O Lord" from Jonah (2:25)

Track 204. "Billows foam" from Jonah (1:45)

Samuel Felsted: Jonah [CD]. (2002).

Bamberg, Germany: Cavalli. (one disc) (disc also includes Mozart's Te Deum, K. 141 and Salieri's Krönungs)

Track 3. Overture

Track 4. Jonah, arise!

Track 5. Out of the Deep, O God, I cry
Track 6. Billows foam around my head

Track 7. The Lord commands; My God and King

Track 8. Jonah, arise again; Lord I obey

Track 9. Repent, ye men of Nineveh

Track 10. Have mercy, Lord

Track 11. God saw their works; Tune your harps

\section{Russell}

Nyaho, W. H. C. (2003). Senku: Piano music by composers of African descent [CD]. Newtown, CT: MSR Classics. (MSR1091; one disc, 73:17)

Track 4. Jamaican dance, no. 1 (1:02)

Track 5. Jamaican dance, no. 2 (2:27)

Track 6. Jamaican dance, no. 3 (1:56)

Shaw, P. (2001). Le grand tour: Paul Shaw plays Caribbean art music [CD].

Track 7. Jamaican dance, no. 1 (0:55)

Track 8. Jamaican dance, no. 2 (2:53)

Track 9. Jamaican dance, no. 3 (1:43)

\section{SOUND FILES}

\section{Alberga}

Available at

http://chevalierdesaintgeorges.homestead.co m/audio.html\#3

[Roald Dahl's "Snow White and the Seven Dwarfs"; String quartet, no. 3; Violin concerto]

Available at http://www.eleanoralberga.com/pages/comp sframeset.htm

"Scherzo" from String quartet, no. 3

"Stepmother's dance from Roald Dahl's

"Snow White and the Seven Dwarfs"

"Duo" from Dancing with the shadow 
"Celebration dance" from Roald Dahl's

"Snow White and the Seven Dwarfs"

The wild blue yonder

Violin concerto, first movement

Violin concerto, first movement, end of cadenza

Violin concerto, second movement, opening

Violin concerto, finale, conclusion

\section{Bellamy}

Available at

http:/www.bellamymusic.com/profile.htm

Improvisations of jackass a jump and bray

\section{Dexter}

Available at

http://www.uwi.edu/uwiofficialsong.aspx?sf lang=en

[The Official University Song (University of the West Indies)]

\section{WEBSITES}

Eleanor Alberga. (2001). AfriClassical.com: African heritage in classical music. Retrieved from http://chevalierdesaintgeorges.homestead.co m/Alberga.html

Parker, C. J. (n.d.) Frederic H. Cowen: Composer, conductor and pianist. Retrieved from

http://www.btinternet.com/ john.parker17/i ndex.html

Jamaica's classical musicians. (2007).

Retrieved from http://www.joyousjam.com/jamaicasclassica lmusicians/index.html

\section{BOOKS, ARTICLES \& THESES}

Chambers, A. C. (1997). Frederic Hyman Cowen: Analysis and reception history of his songs for voice and piano. (Doctoral dissertation). Northwestern University. (UMI \# 9814188)

Cowen, F. H. (1913). My art and my friends. London, England: Edward Arnold.

Available at http://www.archive.org/stream/myartmyfrie nds00coweiala\#page/n7/mode/2up

Dox, T. J. (1991). Samuel Felsted of Jamaica. American Music Research Center Journal, 1, 37-46.

Dox, T. J. (1992). Samuel Felsted's "Jonah": The earliest American oratorio. The Choral Journal, 32(7), 27-32.

Eigeldinger, J. J. (1975). Entretien avec Oswald Russell. Revue Musicale de la Suisse Romande, 28, 26-27.

Eleanor Alberga. (1994). Contemporary Music Review, 11(1-2), 5-6. doi:10.1080/07494469400640471

Eleanor Alberga (2010. Grove Music Online. Oxford, England: Oxford University Press.

The European classical music tradition in Jamaica: An exhibition of the National Library of Jamaica. (2010). Jamaica Journal, 32(3), 73.

Frederic Hymen Cowen. (1898). The Musical Times and Singing Class Circular, 39(669), 713-19. doi:10.2307/3366808

Frederic Hymen Cowen, January 29, 1852October 6, 1935. (1935). The Musical Times, 76(1113), 1008. doi:10.2307/920382

Frederic Hymen Cowen. (2010). Grove Music Online. Oxford, England: Oxford University Press.

Jamaican Music. (2010). Grove Music Online. Oxford, England: Oxford University Press. 
Marks, A. S. (1997). Benjamin West's

"Jonah": A previously overlooked illustration for the first oratorio composed in the New World. American Art Journal, 28(1/2), 122-37. doi:10.2307/1594614

O'Gorman, P. (1988). Art music in Jamaica. Jamaica Journal, 21(3), 39-48. Retrieved from Digital Library of the Caribbean website:

http://ufdc.ufl.edu/UF00090030/00061/41j

O'Gorman, P. (1988). “Jamaican Dance” by Oswald Russell: A descriptive analysis. Jamaica Journal, 21(1), 49-54. Retrieved from Digital Library of the Caribbean website: http://ufdc.ufl.edu/UF00090030/00059/51j

O'Gorman, P. (1986). Jamaican music, cultural modes and composers. Jamaica Journal, 19(1), 41-46. Retrieved from Digital Library of the Caribbean website: http://ufdc.ufl.edu/UF00090030/00050/43j

O'Gorman, P. (1989-1990). “Jonah”: An eighteenth century Jamaican oratorio: Part 1. Jamaica Journal, 22(4), 41-45. Retrieved from Digital Library of the Caribbean website: http://ufdc.ufl.edu/UF00090030/00084/43j

O'Gorman, P. (1990). “Jonah”: An eighteenth century Jamaican oratorio: Part 2. Jamaica Journal, 23(1), 14-19. Retrieved from Digital Library of the Caribbean website: http://ufdc.ufl.edu/UF00090030/00064/16j

Oswald Russell. (2010). Grove Music Online. Oxford, England: Oxford University Press.
Parker, C. J. (2007). The music of Sir Frederic Hymen Cowen (1852-1935): a critical study. (Unpublished doctoral dissertation). University of Durham. (OCLC\# 500353522)

Potts, J. E. (1953). Sir Frederic Cowen (18521935). The Musical Times, 94(1326), 351-3. Available at http://www.jstor.org/stable/934999

Russell, D. (1993). Oswald Russell: Un océan d'amour à l'occasion de son 60e anniversaire. Geneva, Switzerland: Éditions Danielle Russell. (OCLC \# 39120933)

Smither, H. E. (1987). A history of the oratorio, Vol. 3. Chapel Hill, NC: University of North Carolina Press.

[Part II, Chapter V: "Samuel Felsted: Jonah", pp. 311-330.]

Walker-Hill, H. (1995). Music by black women composers: A bibliography of available scores. Chicago, IL: Center for Black Music Research. (OCLC\# 31971765) [Includes list of works by Eleanor Alberga]

\section{LIBRARIES}

Dominique-René de Lerma papers.

The Center for Black Music Research (CBMR). Columbia College Chicago, IL.

Finding aid available at http://www.colum.edu/CBMR/PDF_folder/F inding\%20Aids/CBMR_de_Lerma.pdf

[Don Shirley] 